\title{
Iono-molecular Separation with Composite Membranes. VII. Nitrophenols pertraction on capilary polypropylene S-EPDM composite membranes
}

\author{
ION MARIUS NAFLIU ${ }^{1}$, HUSSAM NADUM ABDALRAHEEM AL ANI ${ }^{1,2}$, ALEXANDRA RALUCA GROSU (MIRON) ${ }^{1}$, \\ SZIDONIA KATALIN TANCZOS ${ }^{3 *}$, IOANA MAIOR ${ }^{1}$, AURELIA CRISTINA NECHIFOR ${ }^{1 *}$ \\ 1Politehnica University of Bucharest, Faculty of Applied Chemistry and Material Science, Analytical Chemistry and Environmental \\ Engineering Department, 1-7 Gheorghe Polizu, 011061, Bucharest, Romania \\ Institute of Technology- Baghdad, Middle Technical University, Baghdad, Iraq \\ ${ }^{3}$ Sapientia University, Str. Libertatii., 500104, Mircurea Ciuc, Romania
}

In the present paper the authors study the pertraction of the nitrophenols through the immobilization using chemical reaction in receiving phase, using a laboratory installation conceived by the Group of Membranes, Materials and Membrane Processes within University Politehnica of Bucharest. This installation was developed using liquid synthetically solutions, through composite membranes having a matrix of capillary polypropylene and inclusions of ethylene propylene diene terpolymer sulfonic acid (S-EPDM) or sulfonated ethylenepropylene-diene terpolymer (S-EPDM). The results were follow: The permeation through the compartments of the system with composite S-EPDM membranes is limited, in the aqueous phases, by the solubility of the compound about to be separated, namely the membrane itself, and subsequently by its diffusion from the feed compartment to the collection compartment. The chemical reaction of immobilization, in the receiving phase, can be achieved in several variants (neutralization, esterification, complexation, oxidation, coupling, oxidative degradation); The biggest flows are obtained in compensation of the o-nitrophenol with ferric ions and then, in acetylation of the o-nitrophenol with acetic anhydride. However, we can emphasize that the derivatization of the o-nitrophenol through complexation and acetylation reactions requires its use as such in later processes, unlike the neutralization, for which the nitrophenolate ion easily frees the nitrophenol for future applications; For the neutralization reaction, the removing coefficient grows with decreasing of $p K a$ value of the nitrophenols. For complexation reaction, the most favorable results were obtained for o-nitrophenol - over 66\%; The coupling reaction of the o-nitrophenol, in the receiving phase, with the diazonium chloride of the p-nitroaniline and hydrogen peroxide $3 \%$ in sulfuric acid $20 \%$, respectively, concludes with the exhaustion of the source phase, after 24 hours of operation.

Keywords: composite membranes, EPDM, pertraction, nitrophenols separation, membrane processes

The impact of the pollution over the quality of the environment is usually related to the urban agglomeration, although even smaller areas can also suffer of it, be them less industrialized or geographically isolated areas [1-5]. For those remote areas, among the specific pollutants, the most interesting to study are the organic compounds, especially the phenols $[5,6]$. Due to their many applications, the phenols are among the most widespread and harmful for the environment, with negative implications both for fauna and flora but especially for the health of the population [7-10]. The study of the impact but especially of the removal of phenols from effluents constitutes a solid argument for the research on the phenols' separation [1116]. Pursuing the development of the recuperative selective separations of the phenols from the liquid effluents, the current researches are oriented toward simpler processes - from technical perspective, and more efficient- from the economical point of view [17-19]. Although in the last decade promising results were obtained with respect to the separation and recuperative concentration of the phenols using: liquid membranes [20,21], pervaporation [22-24], colloidal ultrafiltration [25, 26], and different composite membranes [27-30], notall the technical issues have entirely been solved so far. All the previous reasons suggest that the pertraction would be a possible solution, representing one of the most attractive membrane separation processes, competing with the dialysis, electrodialysis and liquid membranes [31-33]. Although apparently this method seems poor from technical and economical points of view, since the actual membranes are more elaborate and more expensive, the pertraction represents a membrane process that combines permeation through the membranes with the immobilization reaction of the component transported in a collector compartment (fig. 1), for instance the neutralization reaction $[34,35]$. Thereby, the pertraction is a membrane technique in which a soluble component, e.g. the phenol, is separated by diffusion through a selective non-porous membrane starting from a liquid phase (the source solution, SP) and finally collected, during the reception phase (RP) using a chemical reaction [36,37]. The membranes for pertraction can be either composite (fig. 2a) or solvents that are interposed in-between two semi-waterproof membranes (fig. $2 b$ ).

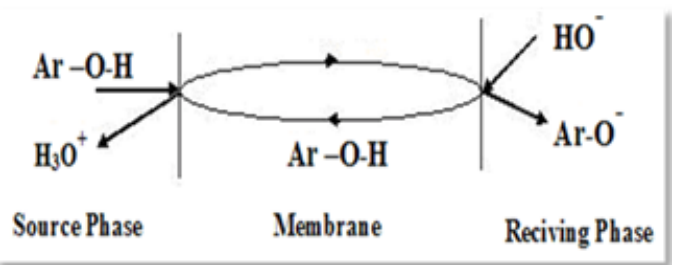

Fig. 1. The general schema for the pertraction of the phenols: the considered Ar-OH phenol

\footnotetext{
*email: tczszidonia@yahoo.com; aureliacristinanechifor@gmail.com
} 


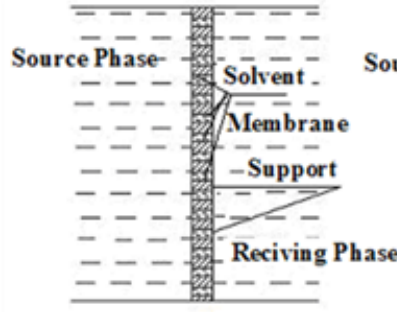

(a)

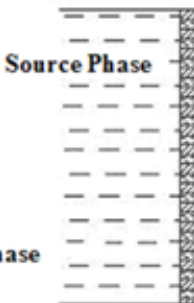

(b)
Fig. 2. Versions of the pertraction membranes: a) composite membrane (membrane solvent in the support membrane pores);

b) membrane solvent in-between two semi-waterproof membranes

The mass transfer through the membrane phase, during pertraction, as with other membrane processes, is based on the difference between the chemical potential of the dissolved substance in the two aqueous solutions. Thus, the flow intensity is controlled by the difference in concentration and/or chemical potential [34-36].

The driving force for membrane mass transfer is due to the application of a chemical potential gradient, accentuated by the immobilization of the compound which is separated in the receiving phase [37, 38].

The mass transfer through membrane consists in three successive stages [37-39]:

-the selective adsorption in the membrane;

-the selective diffusion in the membrane;

-the chemical reaction of immobilization of the separated component.

In the present paper the authors study the pertraction of the nitrophenols through the immobilization using chemical reaction in receiving phase, using a laboratory installation conceived by the Group of Membranes, Materials and Membrane Processes within University Politehnica of Bucharest. This installation was developed using liquid synthetically solutions, through composite membranes having a matrix of capillary polypropylene and inclusions of ethylene propylene diene terpolymer sulfonic acid (S-EPDM) or sulfonated ethylene-propylene-diene terpolymer (S-EPDM).

\section{Experimental part}

Materials and methods

All reagents used (potassium hydroxide, chloride acid $37 \%$, ethyl alcohol, acetic anhydride, acetic acid, benzene, hydrogen peroxide $30 \%$, potassium dichromate, sulfuric acid $(96 \%)$, sodium nitrite, ferric chloride $\left(\mathrm{Cl}_{3} \mathrm{Fe} * 6 \mathrm{H}_{2} \mathrm{O}\right)$ were of analytical purity (Merck); the $0-, \mathrm{p}$-, $\mathrm{m}$ - nitrophenols and 2,4 dinitrophenol come from Sigma-Aldrich.

\section{Procedures}

a)The preparation of the composite polymeric system

The 4 sulpho-EPDM ionomers are formed by sulfonation of the pendant unsaturation in the elastomeric backbone of ethylene-propylene-diene terpolymer (EPDM) followed by neutralization of the resultant EPDM sulfonic acid [40].

The capillary polypropylene membrane (PP) immerses itself into 8\% S-EPDM solution in benzene and then coagulates in an ethanol bath and dries up. Following all these the composite S-EPDM-PP membrane is obtained (fig. 3).

\section{b) The membranes characterization}

Samples from the membrane (capillary fibers of $2 \mathrm{~cm}$ ) are transmitted through SEM microscopy characterization (using a FESEM Hitachi S4500 microscope).

The images obtained using the microscopy based upon the scanning electron technique allow highlighting the porosity of the surface as well as the micro-structure of the composite membrane (fig. 4-a and 4-b).

Ig of composite membrane was titrated with potassium hydroxide ethanolic solution $0.05 \mathrm{M}$ to give an ionic exchange capacity of $2.3 \mathrm{meq} / \mathrm{g}$.

\section{c) The pertraction of the nitrophenol solution}

The synthetical solution of nitrophenol (from SigmaAldrich) having a concentration of $1-10 \mathrm{mg} / \mathrm{L}$ is introduced into a laboratory facility for pertraction (fig. 5), that provides an effectively mass transfer surface of $1 \mathrm{~m}^{2}[33,34]$. The synthetical liquid nitrophenol solutions in the feed are periodically analyzed (using a CAMSPEC spectrometer) [4143].

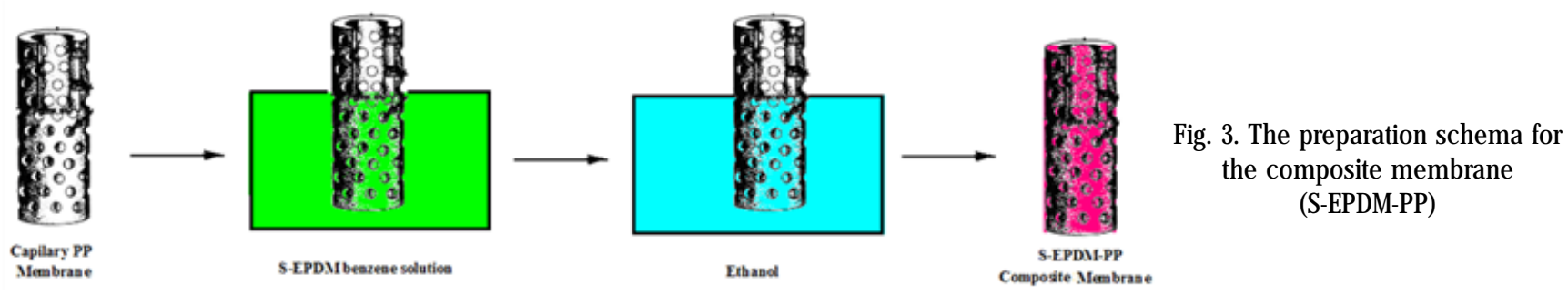

Fig. 4. The Scanning Electron Microscopy:

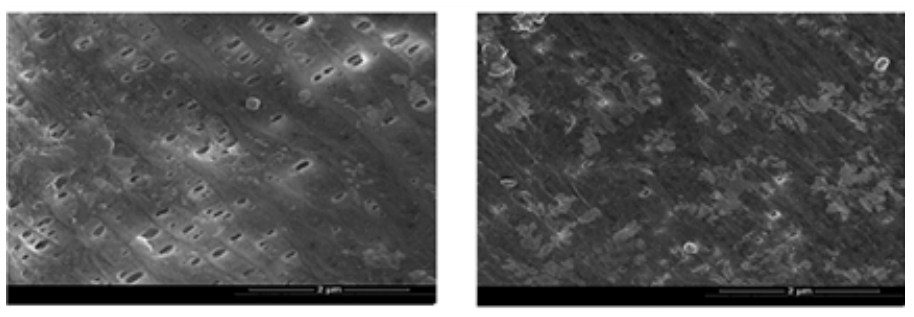

a) the porosity of the surface; b) the micro-structure of the S-EPDM-PP composite membrane

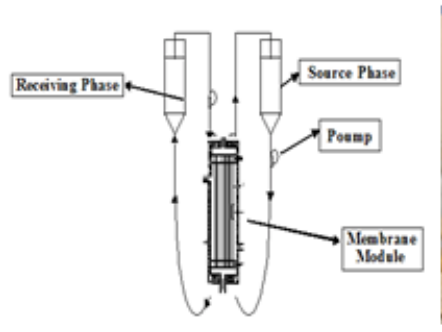

$\mathbf{a}$
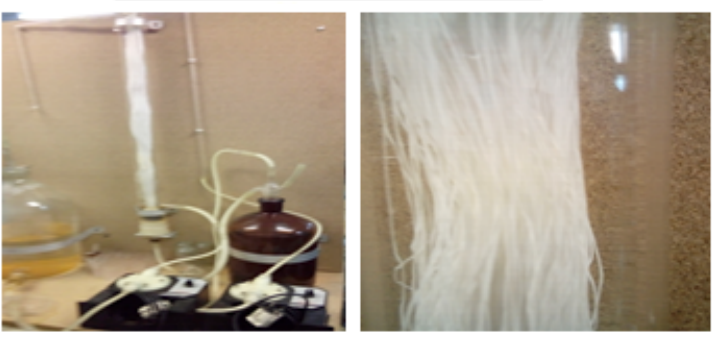

b
Fig. 5. The pertraction module: a) Installation scheme, b) assembly image, c) PP fibers detail 

reservoirs for the liquid solutions - which are recirculated using peristaltic pumps [27, 34].

The flows were computed according to the permeate mass that was measured within a well determined time range, using equation (1):

$$
J=\frac{M}{S \cdot t} \quad\left(\mathrm{Kg} / \mathrm{m}^{2} \mathrm{xh}\right) \quad \text { or } \quad\left(\mathrm{mol} / \mathrm{cm}^{2} \mathrm{~s}\right)(1)
$$

where: $M=$ the permeate mass $(\mathrm{Kg})$

$\mathrm{S}=$ the effective surface of the membrane $\left(\mathrm{m}^{2}\right)$

$t=$ the time necessary for collecting the permeate volume (h) using the absorbance and concentration of the solutions [44-48]:

$$
\mathrm{R}(\%)=\left[\left(\mathrm{c}_{0}-\mathrm{c}_{f}\right) / \mathrm{c}_{0}\right]^{*} 100
$$

where: $c_{f}$ is the final concentration of the solute (nitrophenol),

$$
\mathrm{C}_{0} \text { - initial concentration of solute (nitrophenol) }
$$

The pertraction installation has a main body (fig. 5) and

The removing coefficient of the species of interest $(R)$

$$
R(\%)=\left[\left(A_{0}-A_{\text {sample }}\right) / A_{0}\right] * 100
$$

where: $A_{0}$-the absorbance of the initial solution samples A

A series of membranes were investigated from their morphological point of view by Scanning Electron Microscopy (SEM) using the FESEM Hitachi S 4500 device.

\section{Results and discussions}

The approached nitro-phenolic composites can be schematically synthesized using geometrical shapes of different sizes (fig 6): the solubility (by a rectangle) and the acidity (by a circle).

The images presented in figure 6 suggest big differences among the solubility and acidity of the nitrophenols, which can be operationally exploitable in various separations.

Thus, if the permeation through the system's compartments is limited, in the liquid phases, by the solubility of the composite about to be separated, namely the membrane, and subsequently by its diffusion from the feed compartment to the collection compartment, then the chemical reaction of immobilization, in the receiving phase, can be achieved in several variants (fig. 7 a-f):

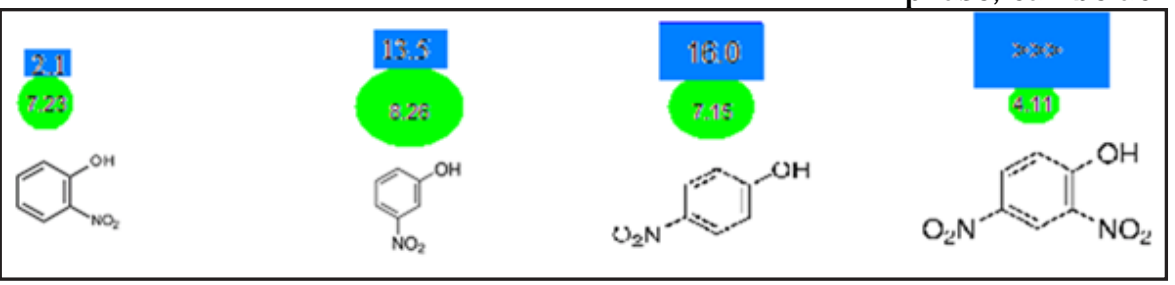

Fig. 6 . The schematic representation of the solubility and acidity of the nitro-phenols

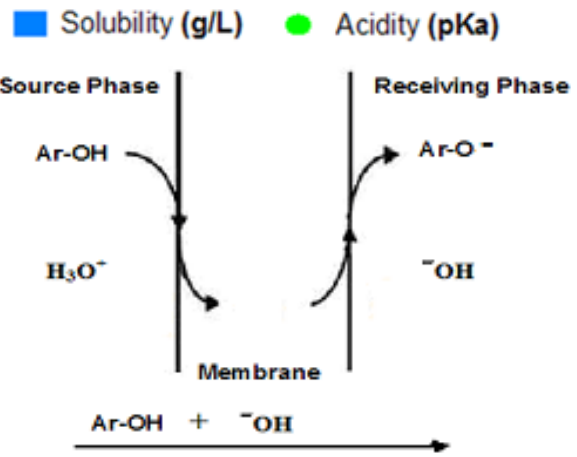

$a$

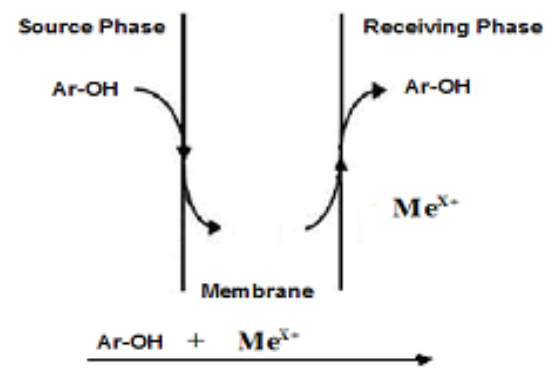

c

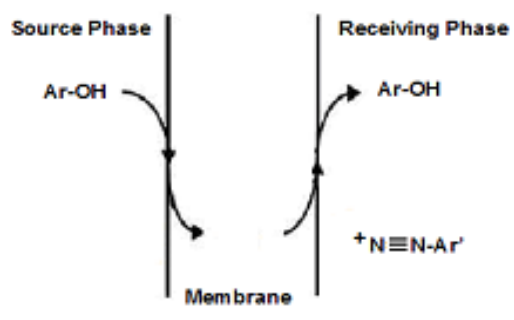

Ar-OH $+{ }^{+} \mathrm{N} \equiv \mathrm{N}-\mathrm{Ar}$

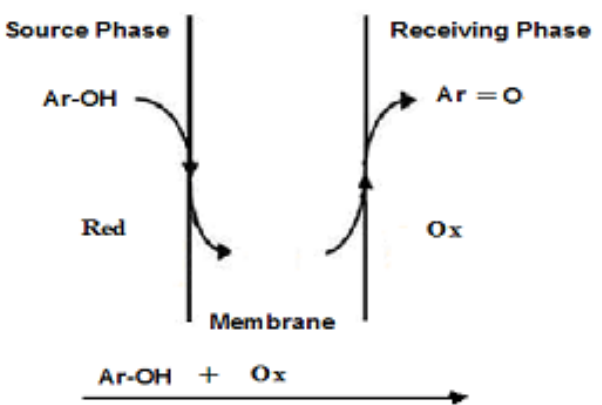

$b$

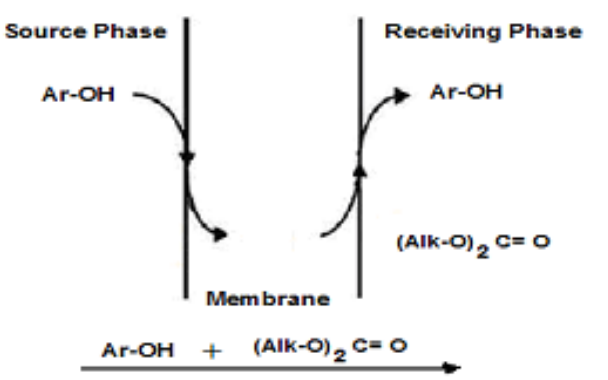

Fig. 7. Main schemes of the membrane process of pertraction, using chemical reaction of: a) neutralization; b) chemical oxidation; c) complexation;

d) esterification; e) coupling; f) oxidative degradation 
a)neutralization;

b)chemical oxidation;

c) complexation;

d)esterification;

e)coupling;

f) oxidative degradation.

In a limiting situation, the collection of the permeate composite takes place in a receptor compartment that contains a strong oxidant. Unfortunately, this process eventually destroys the phenol.

Using the above presented schemes, the reaction of immobilization by neutralization (fig. 7-a) of the 0nitrophenol within the collector compartment was studied - based upon two initial nitrophenol concentrations, both being under the solubility limit. Although theoretically, the concentration gradient is almost constant - since the feed solution has a $\mathrm{pH}$ of 5 and a large volume (5L), and the collection solution has a $\mathrm{pH}$ of 12 and low volume (500 $\mathrm{mL}$ ) - the flow decreases relatively quickly, halving itself after around 5 hours of operation (fig. 8).

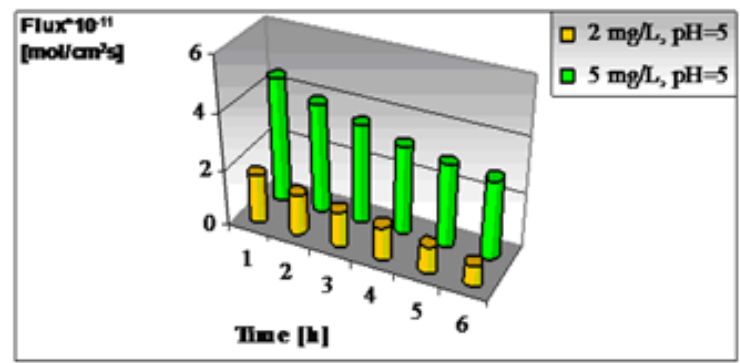

Fig. 8.The flow of nitrophenol for a source phase with $\mathrm{pH}=5$ and $\mathrm{c}$ receiving phase with $\mathrm{pH}=12$

To optimize the flow of o-nitrophenol through the membrane a comparative study was performed, with respect to the permeation variation, from a source phast having a concentration of $5 \mathrm{mg} / \mathrm{L}$ of 0 -nitrophenol ir solutions with variable $\mathrm{pH}(2 ; 5$ and 8$)$ - to a receivin solution having a $\mathrm{pH}$ of 12 (fig. 9).

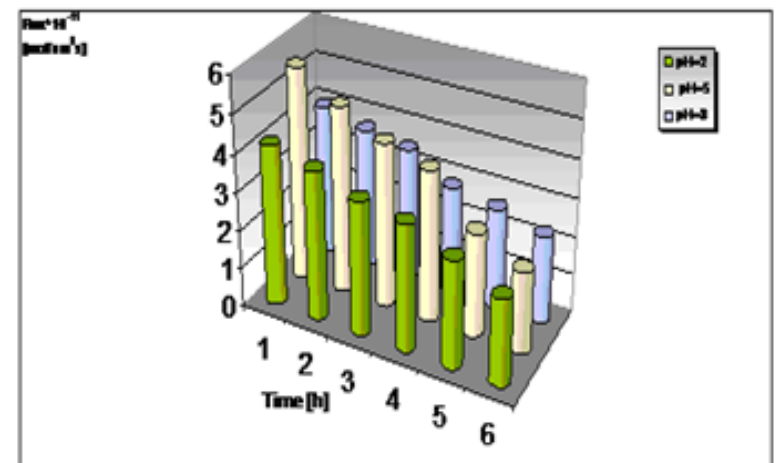

Fig. 9. The o-nitrophenol flow comparison: from a variable $\mathrm{pH}$ (2; 5 and 8) for the source phase of $5 \mathrm{mg} / \mathrm{L}$, to a $\mathrm{pH}$ of 12 for the receiving phase

The experiments show that the best results are obtained for a $\mathrm{pH}=5$ for the source phase. This shows that the composite membrane actively participates in the transfer of the o-nitrophenol. This membrane has a sulfonic component with a maximum transport capacity for $\mathrm{pH}=5$, in the source phase.

For the further experiments we kept the source phase values at: $5 \mathrm{~L}, \mathrm{pH}=5$ and $5 \mathrm{mg} / \mathrm{L}$ o-nitrophenol and varied the reactive component of the receiving phase solution (500 mL), as follows: ferric chloride, potassium hydroxide and acetic anhydride in acetic acid - each having a concentration of $10^{-2} \mathrm{M}$ (fig. 10).

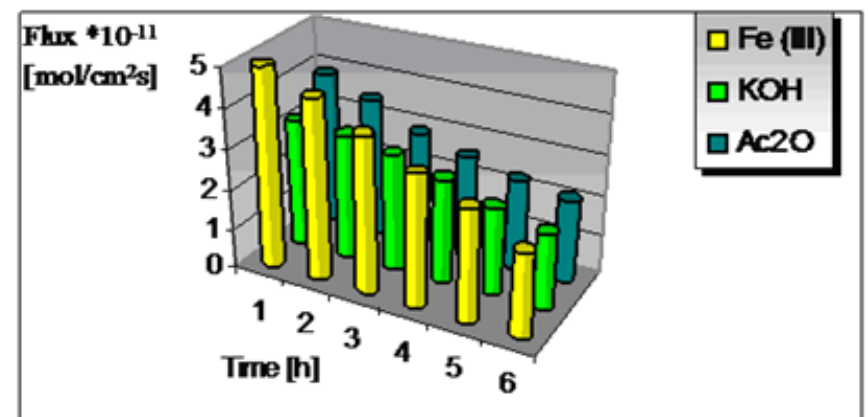

Fig. 10. The 0-nitrophenol flow at $p H=5$ for a source phase with $5 \mathrm{mg} / \mathrm{L}$ and a receiving phase solutions of: ferric chloride, potassium hydroxide and acetic anhydride in acetic acid, each having a concentration of $10^{-2} \mathrm{M}$.

The biggest flows are obtained for both the complexation of o-nitrophenol with ferric ions and the acetylation of onitrophenol with acetic anhydride. However, we can highlight that the o-nitrophenol's derivatization through complexation and acetylation reactions require, for subsequent processes, its usage as such, unlike neutralization, for which the nitrophenolate ion easily frees the nitrophenol in the future applications. Promising results were obtained for the transfer of the nitrophenol from a source phase of $5 \mathrm{mg} / \mathrm{L}$ and $p \mathrm{H}=5$, to a receiving phase with $\mathrm{pH}=0$ and a concentration of $10^{-2} \mathrm{M}$ potassium dichromate or hydrogen peroxide (fig. 11).

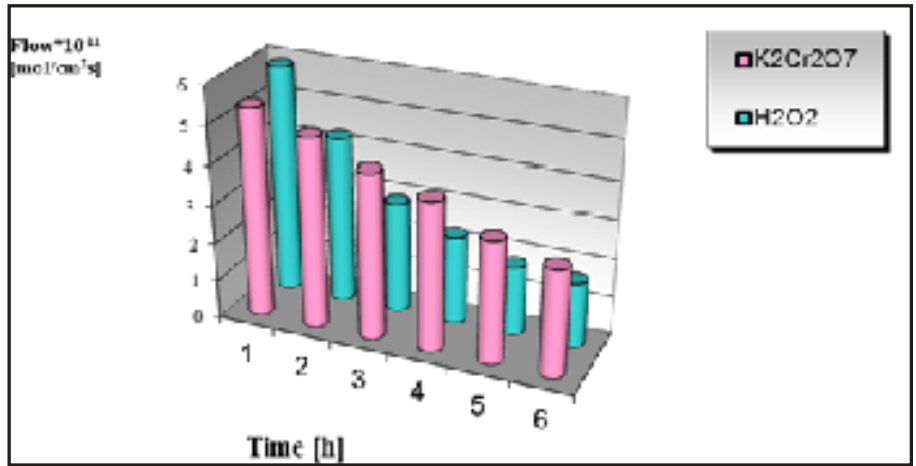

Fig. 11. The flow of o-nitrophenol at $\mathrm{pH}=5$ for the source phase with $5 \mathrm{mg} / \mathrm{L}$ and a receiving phase using solution with $\mathrm{pH}=0$ and concentration of $10^{-2} \mathrm{M}$ potassium dichromate or hydrogen peroxid

The experiments related to the transport through the composite membrane performed using o-nitrophenol show variations of the flow between $2^{*} 10^{-11} \mathrm{~mol} / \mathrm{cm} \mathrm{s}$ and $5^{*} 10^{-11} \mathrm{~mol} / \mathrm{cm} \mathrm{s}$, given the conditions of the following reactions: neutralization, esterification, complexation and oxidation.

For the studies related to the removing coefficient and selectivity in separation of the nitrophenol, the transport results imposed the following: the concentration of the nitrophenols: $5 \mathrm{mg} / \mathrm{L}$; the $\mathrm{pH}$ for the source phase: 5 ; the concentration of the reactants for the receiving phase: $10^{-2} \mathrm{M}$; the reactant species: the hydroxyl ion (in neutralization) and ferric ion (in complexation).

Using an equimolar mixture for the source phase, comprising of 0-, p-, m-nitrophenol and 2,4-dinitrophenol, after $24 \mathrm{~h}$ of operation we obtained the data shown in table 1.

For the neutralization reaction the removing coefficient increases with decreasing of pKa value for nitrophenols while for the complexation, the most favorable results were obtained for 0-nitrophenol, namely over $66 \%$ (see table 1).

In a separate experiment we dealt with the coupling reaction, in the receiving phase, between the o-nitrophenol 
Table 1

THE REMOVING COEFFICIENT OF THE NITROPHENOLS USING COMPOSITE MEMBRANES S-EPDM-PP THROUGH NEUTRALIZATION AND COMPLEXATION REACTIONS

\begin{tabular}{|c|c|c|c|c|}
\hline $\begin{array}{c}\text { Removing coefficient, } \\
\%\end{array}$ & 0-nitrophenol & p-nitrophenol & m-nitrophenol & 2,4 dinitrophenol \\
\hline reaction using $\mathrm{HO}^{-}$ & $\mathbf{5 5 . 8}$ & 56.4 & 47.9 & 70.2 \\
\hline reaction using $\mathrm{Fe}^{3+}$ & 66.1 & 43.6 & 36.7 & 51.4 \\
\hline
\end{tabular}

and both the diazonium chloride of $p$-nitroaniline and hydrogen peroxide $3 \%$ in sulfuric acid $20 \%$, respectively. In both situations, after $24 \mathrm{~h}$ of operation, the solution of 0 nitrophenol $5 \mathrm{mg} / \mathrm{L}$ in the source phase was completely consumed. However, these last two presented alternatives are useful if we either want to recover the nitrophenol as azoic colorant, or its complete degradation.

\section{Conclusions}

The pertraction of the nitrophenols through the chemical reaction of immobilization in the receiving phase, using one of the liquid synthetical solutions, throughout composite membranes with capillary polypropylene matrix and with inclusions of acid ethylene propylene diene terpolymer sulfonic (S-EPDM) or sulfonated ethylenepropylene-diene terpolymer (S-EPDM) led to the following results:

- the permeation through the compartments of the system with composite S-EPDM membranes is limited, in the aqueous phases, by the solubility of the compound about to be separated, namely the membrane itself, and subsequently by its diffusion from the feed compartment to the collection compartment. The chemical reaction of immobilization, in the receiving phase, can be achieved in several variants (neutralization, esterification, complexation, oxidation, coupling, oxidative degradation);

- the biggest flows are obtained in compensation of the o-nitrophenol with ferric ions and then, in acetylation of the o-nitrophenol with acetic anhydride. However, we can emphasize that the derivatization of the o-nitrophenol through complexation and acetylation reactions requires its use as such in later processes, unlike the neutralization, for which the nitrophenolate ion easily frees the nitrophenol for future applications;

- for the neutralization reaction, the removing coefficient grows with decreasing of pKa value of the nitrophenols. For complexation reaction, the most favorable results were obtained for o-nitrophenol - over 66\%;

- the coupling reaction of the o-nitrophenol, in the receiving phase, with the diazonium chloride of the $p$ nitroaniline and hydrogen peroxide $3 \%$ in sulfuric acid $20 \%$, respectively, concludes with the exhaustion of the source phase, after 24 hours of operation.

Acknowledgements: The authors have a gratefully acknowledge: Dr. Constantin ANDREI from ITEC Brazi for S-EPDM samples and Mrs. Roxana TRUSCA for SEM analysis.

\section{References}

1.BUNGAU, S., TIT, D.M., FODOR, K., CIOCA, G., AGOP, M., IOVAN, C., CSEPPENTO, D.C., BUMBU, A., BUSTEA, C., Sustainability, 2018, 10, 2788. doi:10.3390/su10082788

2.SZEP, R., MATEESCU, E., NECHIFOR, A. C., KERESZTESI, Á., Environ. Sci. Pollut. Res., 24, no. 35, 2017, p. 27288.

3.ILIE, M., MARINESCU, F., SZEP, R., GHITA, G., DEAK, GY., ANGHEL, A.M., PETRESCU, A., URITESCU, B., Carpath. J. Earth. Env., 12, no. 2, 2017, p. 437

4.SZÉP, R., KERESZTES, R., KORODI, A., TONK, SZ.,NICULAE, A.G., BIRLOIU, A.M., Rev. Chim.(Bucharest), 67, no. 10, 2016, p. 1914.
5.LEE, A., ELAM, J.W., DARLING, S.B., Environmental Science Water Research \& Technology, 2, 2016, p. 17

6.PETZOLD, G., SCHWARZ, S., Separation and Purification Technology, 31, 2003, p. 318

7.ARDELEAN, R., DAVIDESCU, C.M., POPA, A., Adsorption of p-Nitro phenol from Water on Polymeric Adsorbents, Chem. Bull.Politehnica Univ. Timisoara, 55, 2010, p.132

8.KERESZTESI, Á., PETRES, S., GHITA, G., DUMITRU, F.D., MONCEA, M.A., OZUNU, A., SZEP, R., Rev. Chim. (Bucharest), 69, no.1, 2018, p. 57. 9.JIANG, ZHEN-MAO, LI, AI-MIN, CAl, JIAN-GUO, WANG, CHUN, ZHANG, QUAN-XIN, Journal of Environmental Sciences, 19, 2007, p. 135. 10.FODOR, K., TIT, D.M., PASCA, B., BUSTEA, C., UIVAROSAN, D., ENDRES, L., IOVAN, C., ABDEL-DAIM, M., BUNGAU, S., Oxidative medicine and Cellular Longevity, 2018, ID 4147320, 10 pgs., https:// doi.org/10.1155/2018/4147320

11.SZEP, R., BODOR, Z., MIKLOSSY, I., NIA, I.A., OPREA, O.A., KERESZTESI, Á., Sci. Total Environ., 647, 2019, p. 275.

12.AL ANI, H.N.A., CIMBRU, A.M., TRISCA-RUSU, C., TANCZOS, S.K.., CUCIUREANU, A., NECHIFOR, A.C., Rev. Chim. (Bucharest), 68, no. 2, 2017, p. 203.

13.AL ANI, H.N.A., CIMBRU, A.M., DIN, I.S., TANCZOS, S.K., NAFLIU, I.M., CUCIUREANU, A., Mat. Plast., 54, no. 2., 2017, p. 353.

14.AL ANI, H.N.A., CIMBRU, A.M., TANCZOS, S.K.., DIN, I.S., CUCIUREANU, A., NAFLIU, I.M., NECHIFOR, G., Rev. Chim. (Bucharest), 68, no. 3, 2017, p. 427.

15.RIKABI, A.A.K.K., NECHIFOR, A.C., MOHAMMED, T. J., OPREA, O., MIRON, A.R., SEGARCEANU, M., VAIREANU, D.I., Rev. Chim. (Bucharest), 67, no. 8, 2016, p. 1489.

16.SZEP, R., MATEESCU, E., NITA, A., BIRSAN, M., BODOR, Z., KERESZTESI, A., Atmos. Res., 214, 2018, p. 311. doi:10.1016/ j.atmosres.2018.08.009

17.NECHIFOR, G., ALBU, B.G., RATA, D., POPESCU, G., Rev. Chim. (Bucharest), 47, no. 3, 1996, p. 260.

18.RIKABI, A.A.K.K., BALABAN (CHELU), M., HARABOR, I., ALBU, P.C., SEGARCEANU, M., NECHIFOR, G., Rev. Chim. (Bucharest), 67, no. 9,2016, p. 1658.

19.Van der BRUGGEN, B., DAEMS, B., WILMS, D., VANDECASTEELE, C., Sep. Purif. Technol., 22-23, 2001, p. 519.

20.DIACONU I., GIRDEA R., CRISTEA C., NECHIFOR G., RUSE E., TOTU E. E., Rom. Biotech. Lett., 15, no. 6, 2010, p. 5703.

21.DIACONU I., ABOUL-ENEIN H.Y., AL-OMAR M.A., NECHIFOR G., RUSE E., BUNACIU A..A, TOTU. E.E, Arab. J. Chem., 4, no. 1, 2011, p. 99.

22.DIN, I.S., CIMBRU, A.M., ANI, H.N.A.A., NAFLIU, I.M., TANCZOS, S.K., NECHIFOR, G., Rev. Chim. (Bucharest), 69, no. 5, 2018, p. 1084. 23.DIN, I.S., CIMBRU, A.M., RIKABI, A.A.K.K., TANCZOS, S.K., COTORCEA, S.T., NECHIFOR, G., Rev. Chim. (Bucharest), 69, no. 7, 2018, p. 1603.

24.TERESA, A., REIS, M., ONDINA DE FREITAS, M.F., ISMAEL, M.R.C., CARVALHO, J.M.R., J. Membr. Sci., 305, 2007, p. 313.

25.COROBEA, C., DONESCU, D., RADITOIU, V., VOICU, S.I., NECHIFOR, G., Rev. Chim. (Bucharest), 57, no. 9, 2006, p. 981.

26.FRANKENFELD, J.W., LI, N.N., John Wiley \& Sons, Inc., New York, 1987.

27.SEGARCEANU, M., MIRON, A.R., TANCZOS, S.K., RIKABI, A.A.K.K., NAFLIU, I.M., VAIREANU, D.I., Mat. Plast, 55, no.2, 2018, p. 137.

28.GHIMPUSAN, M., NECHIFOR, G., NECHIFOR, A.C., DIMA, S.O., PASSERI, P., J ournal of Environmental Management, 203, 2017, p. 811. 
29.DIACONU, I., ZAHARIA, I., RUSE, E., NECHIFOR, G., Dig. J. Nanomater. Bios., 7, no. 3, 2012, p. 1303.

30.ZAHARIA, I., DIACONU, I., RUSE, E., NECHIFOR, G., Rev. Chim. (Bucharest), 66, no. 2, 2015, p. 169.

31.BALASUBRAMANIAN, A., VENKATESAN, S., Pol. J. Chem.Tech., 14, 2012, p.46

32.TAN, B.H., TENG, T.T., OMAR, A.K.M., Wat. Res., 34, no.2, 2000, p. 597.

33.NECHIFOR, G., ALBU, B.G., RATA, D., POPESCU, G., Rev. Chim. (Bucharest), 47, no. 3, 1996, p. 260.

34.DIACONU I., NECHIFOR G., NECHIFOR A.C., RUSE E., TOTU, E.E., UPB.Sci.Bull. Serries B, 71, no.4, 2009, p. 61.

35.WAGNER, K., SCHULZ, S., J. Chem. Eng. Data, 46, 2001, p. 322.

36.MITTAL, K.L., SHOH, D.O., Surfactants in solution, Vol. 11, Springer Science\&Business Media New York, 1991.

37.DIACONU, I., NECHIFOR, G., NECHIFOR, A.C., TOTU, E.E, RUSE, E., Rev. Chim.(Bucharest), 60, no. 12, 2009, p. 1243.

38.BADEA, M., CHIPEREA, C., BALAN, M., FLOROIAN, L., RESTANI, P., MARTY J .-L., IOVAN, C., TIT, D. M., BUNGAU, S., TAUS, N., Farmacia, 66, nr. 1, 2018, p. 83.
39.POPESCU, G., NECHIFOR, G., ALBU, B., LUCA, N., Rev. Roum. Chim., 34, no. 2, 1989, p. 577.

40.MAKOWSKI, H.S., O'FARRELL, C.P., US Patent 4,131,586, 1978 41.CUCIUREANU, A., BATRINESCU, G., BADEA, N.N., RADU, D.A., NECHIFOR, G., Mat. Plast., 47, no. 4, 2010, p. 416.

42.BUNGAU, S., TIT, D. M., IOVAN, C., COPOLOVICI, L., BOSCENCU, R., CIOCA, G., COPOLOVICl, D., Rev. Chim.(Bucharest), 68, nr. 11, 2017; p. 2495.

43.LEE, S.Y., KIM, B.N., HAN, J.H., CHANG, S.T., CHOI, Y.W., KIM, Y. H., MIN, J., J. Hazard. Mat., 182, 2010, p. 936.

44.SZCZEPANSKI, P., DIACONU, I., Separ. Sci. Technol., 47, 2012, p. 1725.

45.SZCZEPANSKI, P., KOTER, S., Separ. Sci. Technol., 46, no. 16, 2011, p. 2465.

46.MA, M., CHEN, B., LUO, X., TAN, H., HE, D., XIE, Q., YAO, S., J. Membr. Sci., 234, 2004, p.101.

47.SZCZEPANSKI, P., Sep. Purif. Technol., 71, no. 1, 2010, p. 121. 48.KOTER, S., SZCZEPANSKI, P., Chem. Pap., 65, 2011, p. 584.

Manuscript received: 19.09 .2018 